\title{
JMT's Research Concepts Section: a 5-Year Evaluation
}

\author{
David H. Jang ${ }^{1,2} \cdot$ Jennifer S. Love ${ }^{1} \cdot$ Mark B. Mycyk $^{3}$
}

Received: 11 July 2019 /Revised: 17 July 2019 / Accepted: 19 July 2019/Published online: 5 August 2019

(C) American College of Medical Toxicology 2019

The Journal of Medical Toxicology launched the Research Concepts section in 2010 to allow investigators to advance their research more quickly [1]. The goals of this section are threefold: (1) to provide a forum for rapid publication of peerreviewed research; (2) to obtain high-level critical reviews from established funded investigators; and (3) to support future grant applications for extramural funding. To meet these goals, this section was open to pilot data as well as novel study concepts to give investigators an opportunity to reach a larger audience with high-risk ideas that had the potential for high impact if carried through to the next step.

Not surprisingly, recruiting submissions was initially slower than for our other sections, but eventually those authors who published their work in Research Concepts were enthusiastic and recommended it to others. Anecdotally, authors who published here attributed subsequent grant funding and collaboration to this publication. Others who did not publish in Research Concepts reported uncertainty as to whether the section could provide the desired advancement.

As we think about how to improve $J M T$ and serve our readers and authors better, we thought this would be the right time to evaluate the JMT Research Concepts section. We systematically reviewed all submissions to the Research Concepts section during the five-year period from 2014 through 2018 to determine if any extramural funding followed publication. In addition to reviewing all relevant manuscript data included in our electronic editorial manager system, first

Supervising Editor: Howard Greller, MD

David H. Jang

David.jang@uphs.upenn.edu

1 Department of Emergency Medicine, Perelman School of Medicine, University of Pennsylvania, Philadelphia, PA 19104, USA

2 Anesthesia and Critical Care Mitochondrial Unit (ACMU), Colket Translational Research Building, Lab 6200, 3501 Civic Center Blvd, Philadelphia, PA 19104, USA

3 Department of Emergency Medicine, Cook County Health, Chicago, IL, USA authors were contacted to determine if there was an association between publication and subsequent grant funding. We specifically inquired about any reference to the manuscript in the grant submission. We considered all forms of extramural funding in our analysis.

From 2014 through 2018, the JMT Research Concepts section published eight articles: each was reviewed by a minimum of two previously funded peer reviewers. Time from submission to first decision averaged 14.1 days; 6 manuscripts required one revision and 2 required multiple revisions before publication [2-9]. Institutional affiliation for the first author included 5 manuscripts for the University of Massachusetts, 2 manuscripts for the University of Pennsylvania, and one manuscript for Iowa State University. Five papers focused on the integration of technology and toxicology, while three papers focused on basic science research. Multiple grants were funded related to the accepted manuscripts, including three National Institutes of Health (NIH) career development awards (K08 and K23), acceptance into an institutional KL2 program, and an NIH R21 CounterACT grant.

Although 8 manuscripts over 5 years does not seem to be a large number, it is important to remember that $J M T$ is only a quarterly journal and the number of active medical toxicology investigators remains quite small. Although $J M T$ prides itself on a rapid decision to authors, it is a point of pride to see the time to first decision for the Research Concepts section is faster than the average for all submitted manuscripts. This is particularly striking considering these manuscripts require peer review by at least two funded investigators, a level of expertise that is much higher and more difficult to recruit than for our other manuscript submissions. Supporting this "forum for rapid peer review and publication" meets the first goal mentioned by Steve Bird in the inaugural editorial that explained the purpose of this section [1]. Second, learning from the first authors about the many different extramural grants that were awarded to them following their publication in $J M T$ meets the greater NIH benefit mentioned in that same editorial. As scientists we need to acknowledge that causation should not be claimed: we cannot say these authors would not 
have been successfully funded without publishing in $J M T$, but it is fair to suggest that the opportunity provided by this section for preliminary work was helpful.

The majority of medical toxicologists today are primarily trained in Emergency Medicine, a larger and more organized specialty than Medical Toxicology. While continuously improving, Emergency Medicine still lags behind other primary care specialties, such as Pediatrics and Neurology, in funded research [10, 11]. One criterion for successful extramural funding is having publications that demonstrate preliminary data, feasibility, and collaboration [12, 13]. We remain convinced the Research Concepts section is vital to the research enterprise of Medical Toxicology. It serves as a forum to publish novel methodologies and obtain rapid peer review from established funded investigators. The time to online publication for all articles in JMT averages only 20 days, an impressive number when compared with many biomedical journals publishing today. This is critical, as early online access will become available to the reviewers of extramural funding agencies such as the NIH. The Research Concepts section can play a crucial role for early-stage investigators to launch a successful research career leveraging this unique forum available to the Journal of Medical Toxicology, and we strongly encourage all scholars to take advantage of this opportunity [14].

Sources of Funding K08HL136858 from the National Heart, Lung, and Blood Institute (DJ)

\section{Compliance with Ethical Standards}

Conflicts of Interest None.

\section{References}

1. Bird SB. Research concepts, collaboration, and JMT. J Med Toxicol. 2010;6(1):1-2.

2. Anantharam P, Kim DS, Whitley EM, Mahama B, Imerman P, Padhi P, et al. Midazolam efficacy against acute hydrogen sulfideinduced mortality and neurotoxicity. J Med Toxicol. 2018;14(1): 79-90. https://doi.org/10.1007/s13181-017-0650-4.

3. Carreiro S, Chai PR, Carey J, Chapman B, Boyer EW. Integrating personalized technology in toxicology: sensors, smart glass, and social media applications in toxicology research. J Med Toxicol. 2017;13(2):166-72. https://doi.org/10.1007/s13181-017-0611-y.

4. Carreiro S, Smelson D, Ranney M, Horvath KJ, Picard RW, Boudreaux ED, et al. Real-time mobile detection of drug use with wearable biosensors: a pilot study. J Med Toxicol. 2015;11(1):739. https://doi.org/10.1007/s13181-014-0439-7.

5. Chai PR, Carreiro S, Ranney ML, Karanam K, Ahtisaari M, Edwards R, et al. Music as an adjunct to opioid-based analgesia. J Med Toxicol. 2017;13(3):249-54. https://doi.org/10.1007/s13181017-0621-9.

6. Chai PR, Wu RY, Ranney ML, Porter PS, Babu KM, Boyer EW. The virtual toxicology service: wearable head-mounted devices for medical toxicology. J Med Toxicol. 2014;10(4):382-7. https://doi. org/10.1007/s13181-014-0420-5.

7. Jang DH, Khatri UG, Mudan A, Love JS, Owiredu S, Eckmann DM. Translational application of measuring mitochondrial functions in blood cells obtained from patients with acute poisoning. J Med Toxicol. 2018;14(2):144-51. https://doi.org/10.1007/s13181018-0656-6.

8. Ouchi K, Lindvall C, Chai PR, Boyer EW. Machine learning to predict, detect, and intervene older adults vulnerable for adverse drug events in the emergency department. J Med Toxicol. 2018;14(3):248-52. https://doi.org/10.1007/s13181-018-0667-3.

9. Skolnik AB, Chai PR, Dameff C, Gerkin R, Monas J, Padilla-Jones A, et al. Teletoxicology: patient assessment using wearable audiovisual streaming technology. J Med Toxicol. 2016;12(4):358-64. https://doi.org/10.1007/s13181-016-0567-3.

10. Jang DH, Levy PD, Shofer FS, Sun B, Brown J. A comparative analysis of National Institutes of Health research support for emergency medicine - 2008 to 2017. Am J Emerg Med. 2018. https:// doi.org/10.1016/j.ajem.2018.12.045.

11. Brown J. National Institutes of Health support for individual mentored career development grants in emergency medicine. Acad Emerg Med. 2014;21(11):1269-73. https://doi.org/10.1111/ acem.12517.

12. Mumma BE, Chang AM, Kea B, Ranney ML, Society for Academic Emergency Medicine Research Committee. Career development awards in emergency medicine: resources and challenges. Acad Emerg Med. 2017;24(7):855-63. https://doi.org/10. 1111/acem.13189.

13. Conte ML, Omary MB. NIH Career Development Awards: conversion to research grants and regional distribution. J Clin Invest. 2018;128(12):5187-90. https://doi.org/10.1172/JCI123875.

14. Robinson GF, Schwartz LS, DiMeglio LA, Ahluwalia JS, Gabrilove JL. Understanding career success and its contributing factors for clinical and translational investigators. Acad Med. 2016;91(4):570-82. https://doi.org/10.1097/ACM. 0000000000000979 .

Publisher's Note Springer Nature remains neutral with regard to jurisdictional claims in published maps and institutional affiliations. 